\section{Conclusion}

The two cases presented highlight the need for vigilance and prompt referral of lesions that are suspicious for oral cancer. There are potentially serious consequences for patients if there are significant delays between the initial presentation of the lesion and referral for specialist opinion.

The key learning points for dental practitioners from our paper are:

- The most common site for SCCs is the tongue, ${ }^{3}$ but they can occur on any mucosal area including the maxilla

- Delay in referral can considerably decrease patient survival, particularly when referral is made at a late tumour stage

- The best possible scenario is referral when the tumour diameter is less than $2 \mathrm{~cm}$

- Thorough and systematic clinical examination of the soft tissues and examination of regional lymph nodes at each appointment helps early detection

- Once the initial management for a presumed benign local cause is unsuccessful and mucosal areas show no resolution, there should be an increased level of suspicion and reconsideration of possible diagnoses

- GDPs should refer cases of concern to their local oral and maxillofacial team early to help avoid the additional morbidities associated with the management of latepresenting tumours.

\section{Acknowledgements}

With thanks to both patients for giving permission for images to be published.

\section{Competing interests}

The authors declare no competing interests.

\section{References}

1. American Joint Committee On Cancer. Cancer Staging manual (8th ed). 2018. Available at https:// cancerstaging.org/references-tools/deskreferences/ Documents/AJCC\%20Cancer\%20Staging\%20 Form\%20Supplement.pdf (accessed May 2020)

2. Oral Health Foundation. State of Mouth Cancer UK Report 2019/2020. 2020. Available at https:// www.dentalhealth.org/Handlers/Download. ashx?IDMF=630bdca4-0634-44cd-b8dd8dab7b6f4d0a (accessed May 2020).

3. Cancer Research UK. Health professional. Available at https://www.cancerresearchuk.org/healthprofessional (accessed May 2020).

4. Mello F W, Melo G, Pasetto J J, Silva C A B, Warnakulasuriya S, Rivero E R C. The synergistic effect of tobacco and alcohol consumption on oral squamous cell carcinoma: a systematic review and meta-analysis. Clin Oral Investig 2019; 23: 2849-2859.

5. Thomas S, Penfold C, Waylen A, Ness A. The changing aetiology of head and neck squamous cell cancer: A tale of three cancers? Clin Otolaryngol 2018; DOI: 10.1111/coa.13144.

6. National Institute of Dental and Craniofacial Research Website. Oral Cancer Incidence (New Cases) by Age, Race, and Gender. 2018. Available at https:// www.nidcr.nih.gov/research/data-statistics/oralcancer/incidence (accessed May 2020).

7. Lewis M A O. Mouth cancer: presentation, detection and referral in primary dental care. Br Dent J 2018; 225: 833-840.

8. Scully C. Oral and Maxillofacial Medicine: The basis of diagnosis and treatment. 3rd ed. London: Churchill Livingstone; 2013.

9. Lyratzopoulos G, Saunders C, Abel G et al. The relative length of the patient and the primary care interval in patients with 28 common and rarer cancers. Br J Cancer 2015112 Suppl 1(Suppl 1): S35-S40.

10. Grafton-Clarke C, Chen K W, Wilcock J. Diagnosis and referral delays in primary care for oral squamous cell carcinomas: a systematic review. Br J Gen Pract 2019; 69: 112-126.

11. MDDUS. Slow-healing Socket. 2018. Available at https://www.mddus.com/resources/resource-library/ case-of-the-month/2018/june/slow-healing-socket (accessed May 2020).

12. Speight $P$, Farthing $P$. The pathology of oral cancer. $B r$ Dent J 2018; 225: 841-847.

13. Department of Health. The NHS Cancer plan: a plan for investment, a plan for reform. 2000. Available at https://www.thh.nhs.uk/documents/_Departments/ Cancer/NHSCancerPlan.pdf (accessed May 2020).

14. National Institute for Health and Care Excellence. Head and Neck Cancers Referral and Recognition. 2016. Available online at https://cks.nice.org. uk/head-and-neck-cancers-recognition-andreferral\#!scenario (accessed May 2020).

15. NHS England and NHS Improvement South West. Suspected Head and Neck Cancer Referral form 2 week wait. 2020. Available online at https://www. england.nhs.uk/south/info-professional/dental/dcis/ forms / (accessed July 2020).

16. Scottish Referral Guidelines for Suspected Cancer. Homepage. 2019. Available at http://www. cancerreferral.scot.nhs.uk/Home (accessed July 2020).

\title{
Correction to: Book review: Orthodontics: diagnosis and management of malocclusion and dentofacial deformities, 3rd Ed
}

The original article can be found online at https://doi.org/10.1038/s41415-020-2571-x

Author's correction note:

Book review article Br Dent J 2021; 230: 10.

When this article was initially published the second author's name was not included. The author list should have read:

'Sagar Dahiya \& Rajat Mitra'

The journal apologises for any inconvenience caused. 